\title{
PEMANFAATAN RUANG TERBUKA KAMPUS SEBAGAI POTENSI MENJAGA LINGKUNGAN
}

\author{
Imas Gandasari' ${ }^{1}$, Oot Hotimah², Mieke Miarsyah ${ }^{3}$ \\ ${ }^{1}$ Mahasiswa Manajemen Lingkungan, Pascasarjana Universitas Negeri Jakarta, \\ Komplek Universitas Negeri Jakarta Gedung M. Hatta Jl. Rawamangun Muka, Jakarta Timur, Indonesia \\ 13220, email: imasgandasarie@gmail.com \\ ${ }^{2}$ Dosen Manajemen Lingkungan, Pascasarjana Universitas Negeri Jakarta, \\ Komplek Universitas Negeri Jakarta Gedung M. Hatta Jl. Rawamangun Muka, Jakarta Timur, Indonesia \\ 13220,email: oothotimah@unj.ac.id \\ ${ }^{2}$ Dosen Manajemen Lingkungan, Pascasarjana Universitas Negeri Jakarta, \\ Komplek Universitas Negeri Jakarta Gedung M. Hatta Jl. Rawamangun Muka, Jakarta Timur, Indonesia \\ 13220,email: mmiarsyah@unj.ac.id
}

\begin{abstract}
Abstrak
Ruang terbuka hijau kini bukan hanya sekadar peraturan yang dicanangkan pemerintah akan tetapi sudah menjadi kebutuhan di perkotaan. Kampus-kampus kini sudah banyak menerapkan konsep ruang terbuka hijau untuk menciptakan kenyamanan dalam kegiatan belajar mngajar. Pola pemanfaatan dan pengembangan ruang terbuka hijau di kampus kini makin beragam. Penelitian ini untuk mengetahui fungsi dan manfaat ruang terbuka hijau di kampus dan arahan yang tepat dalam penerapan konsep ruang terbuka hijau di kampus. Metode penelitian ini menggunakan studi literatur yaitu dengan membahas beberapa jurnal dan penelitian tentang ruang terbuka hijau di kampus yang ada di Indonesia. Dari pembahasan jurnal dan penelitian yang ada dapat diambil kesimpulan bahwa konsep ruang terbuka hijau memiliki banyak manfaat terutama memberikan keindahan dan kenyamanan di kampus selain manfaat jangka panjangnya yaitu sebagai taman obat, penyerap udara kotor, memelihara ketersediaan air dan melestarikan ragam flora dan fauna.
\end{abstract}

Keywords : ruang terbuka hijau, kampus, lingkungan

\begin{abstract}
Green open space is now not just a regulation launched by the government but has become a necessity in cities. Campuses have now implemented a lot of green open space concepts to create comfort in teaching learning activities. The pattern of utilization and development of green open space on campus is now increasingly diverse. This study is to determine the functions and benefits of green open space on campus and the proper direction in applying the green open space concept on campus. This research method uses literature studies by discussing several journals and research on green open spaces on campuses in Indonesia. From the discussion of existing journals and research, it can be concluded that the concept of green open space has many benefits, especially providing beauty and comfort on campus in addition to its long-term benefits, namely as a medicinal garden, absorbing dirty air, maintaining water availability and preserving a variety of flora and fauna.
\end{abstract}

Keywords: green open space, campus, environment 


\section{PENDAHULUAN}

Ruang terbuka saat ini banyak kita temui di berbagai tempat. Lahan yang seharusnya diperuntukan unutk kawasan ruag terbuka hijau pun beralih fungsi smenjadi pusat area pembangunan. Meningkatkan kualitas ekologis suatu kota dapat dilakukan dengan membentuk Ruang Terbuka Hijau pada kawasan perkotaan (Siregar, 2014). Kurangnya ruang terbuka hijau akan memberikan dampak buruk bagi kualitas lingkungan dan kesehatan, untuk itu diperlukan ruang terbuka hijau yang akan meningkatkan kualitas lingkungan perkotaan (Bertiyanti, 2018). Pemanfaatan ruang terbuka menjadi pengurai masalah lingkungan masih menjadi masalah di berbagai wilayah yang ada di Indonesia. Pemerintah sudah mengatur tentang pemanfaatan ruang terbuka menjadi ruang terbuka hijau melalu Permen PU no 8 tahun 2008.

Dalam permen tersebut di atur semua mengenai porsi, jenis dan arahan pemanfaatan ruang terbuka hijau bagi setiap Kawasan. Penataan ruang adalah unsur utama dalam pembangunan dalam sebuah kawasan perkotaan dan merupakan alat untuk mengkoordinasikan pembangunan perkotaan secara berkelanjutan (Shani \& Kurniawan, 2015). Ruang Terbuka Hijau (RTH) yang memadai yang terdapat di perkotaan dapat digunakan sebagai indikator kondisi lingkungan yang baik (Hamdaningsih, Fandeli, \& Baiquni, 2013).
Saat ini bukan hanya di Kawasan perkotaan issu tentang ruang terbuka hijau sudah menjadi penting diterapkan di kampuskampus yang ada di Indonesia. Ruang hijau kampus idealnya memiliki fungsi yang mendukung aktivitas civitas akademika kampus yang mencakup mahasiswa, dosen, dan pegawai (Mochamad, Rogomulyo, \& Rofiko, 2015). Penataan ruang terbuka hijau kota merupakan salah satu upaya perencanaan kota dalam membatasi pembangunan secara berlebihan serta mengatasi dampak ekologis berbagai aktivitas manusia terkait gangguan proses alam pada lingkungan perkotaan (Shani \& Kurniawan, 2015).

Pemenuhuan porsi ruang terbuka hijau telah diatur yaitu $30 \%$ untuk RTH publik dan $10 \%$ RTH privat (Kementrian Pekerjaan Umum, 2008). Sedangkan untuk sekolah masuk dalam kategori RTH taman kelurahan atau taman kecamatan tergantung jumlah populasi penduduknya. Dalam rangka memenuhi kebutuhan Ruang Terbuka Hijau tersebut maka, semua kalangan,wajib memberikan kontribusi, khusunya fasilitasfasilitas umum yang memiliki potensi, seperti kawasan perkantoran, perumahan, pendidikan dan fasilitas umum lain (Hermawan, Pramitasari, \& Sudibyo, 2017). Harus disadari pentingnya perencanaan ruang dan lahan dengan penyediaan RTH yang cukup, sehingga perkembangan ruang terbangun dapat berjalan serasi, selaras, dan seimbang 
dengan ketersediaan RTH, sebagai tuntutan yang utuh dari setiap pelaku yang terlibat didalamnya (Samsudi, 2010).

Ruang Terbuka Hijau (RTH), adalah area memanjang/jalur dan atau mengelompok, yang penggunaannya lebih bersifat terbuka, tempat tumbuh tanaman, baik yang tumbuh tanaman secara alamiah maupun yang sengaja ditanami (Kementrian Pekerjaan Umum, 2008). Ruang terbuka hijau terdiri dari ruang terbuka hijau publik dan ruang terbuka hijau privat.

Perencanaan ruang terbuka hijau (RTH) didasarkan pada pertimbangan dapat terwujudnya keseimbangan, keserasian, dan keselamatan bangunan gedung dengan lingkungan di sekitarnya, serta mempertimbangkan terciptanya ruang luar bangunan gedung dan ruang terbuka hijau yang seimbang, serasi, dan selaras dengan lingkungan di sekitarnya.

Bentuk ruang terbuka hijau dapat diklasifikasikan sesuai dengan tipologinya. Secara fisik ruang terbuka hijau dapat dibedakan menjadi ruang terbuka hijau alami berupa habitat liar alami, kawasan lindung dan taman-taman nasional dan ruang terbuka hijau non alami atau binaan seperti taman, lapangan olahraga, pemakaman atau jalurjalur hijau jalan (Koto \& Taslim, 2019).

Pembangunan ruang terbuka hijau di kampus bisa memberikan dampak positif dalam mendukung kegiatan belajar mengajar, akan tetapi saat ini belum banyak kampus yang menerapkan ruang terbuka hijau menjadi pendukung sarana belajar mengajar. di beberapa kampus seperti Universitas Diponegoro telah memilki ruang terbuka hijau yang seimbang dengan ruang terbangun (Purwanto \& Setioko, 2018).

Bila diteliti lebih jauh ruang terbuka hijau yang ada di kampus-kampus di Indonesia masih jauh berbeda dibandingkan dengan yang ada di kampus-kampus di negara maju (Lapian, 2015). Ruang terbuka hijau menjadi kebutuhan penting di beberapa kampus di negara maju. Mereka berlombalomba memanfaatkan ruang terbuka menjadi ruang terbuka hijau.

Ruang terbuka hijau (RTH) bermanfaat secara ekologis, antara lain mengurangi polusi udara dan memperbaiki sistem tata air kota (Nugradi, 2009). Secara teratur, bentuk dan susunan ruang terbuka hijau merupakan kombinasi antara ekologis, planologis dan manajemen pemerintahan dengan uraian sebagai berikut: (Supriyatno, 2009)

1. Ekologis adalah ruang terbuka hijau yang berbasis bentang alam seperti Kawasan lindung, perbukitan, sempadan sungai, sempadan danau, maupun psisir.

2. Planologis merupakan ruang-ruang yang terbentuk mengikuti pola struktur kota seperti ruang rerbuka hijau perumahan, ruang terbuka hijau keluranan, ruang terbuka hijau kota maupun taman regional atau nasional. 
3. Manajemen pemerintahan adalah

kemampuan aparatur birokrasi

pemerintahan dalam mengelola dan

membangun ruang terbuka hijau yang

dapat meningkatkan kesejahteraan rakyat

seperti adanya bisnis taman-taman kota, perawatan taman kota yang dapat menambah tenaga kerja. Disisi lain dapat menghidupkan kota sebagai tempat wisata.

Pengembangan dan pembangunan kampus yang tidak dilakukan secara sinergis dengan pemanfaatan dan pemeliharaan RTH sebagai hutan kota dapat mengakibatkan kampus menjadi tidak lagi nyaman untuk tempat beraktivitas (Beddu, 2015).

Jenis Ruang terbuka hijau yang termuat dalam Permendagri nomor 1 tahun 2007 tentang ruang terbuka hijau mengklasifikasikan 23 jenis ruang terbuka hijau sebagai berikut (Kementrian Dalam Negri, 2007):

1. Taman kota

2. Taman wisata alam

3. Taman rekreasi

4. Taman lingkungan perumahan dan permukiman

5. Taman lingkungan perkantoran dan gedung komersial

6. Taman hutan raya

7. Hutan kota

8. Hutan lindung

9. Bentang alam seperti gunung, bukit, lereng dan lembah

11. Kebun raya

12. Kebun binatang

13. Pemakaman umum

14. Lapangan olah raga

15. Lapangan upacara

16. Parkir terbuka

17. Lahan pertanian perkotaan

18. Jalur dibawah tegangan tinggi (SUTT dan SUTET)

19. Sempadan sungai, pantai, bangunan, situ dan rawa

20. Jalur pengaman jalan, median jalan, rel kereta api, pipa gas dan pedestrian

21. Kawasan dan jalur hijau

22. Daerah penyangga (buffer zone) lapangan udara

23. Taman atap (roof garden)

Ruang terbuka hijau memiliki dua fungsi, yaitu fungsi utama dan fungsi tambahan. Fungsi utama dari ruang terbuka terdiri dari:

1. Fungsi ekologi

Ruang terbuka hijau merupakan paruparu dari sebuah kota atau wilayah. Tumbuhan atau tanaman dapat menyerap karbondioksida (CO2), menjadi resapan air, memberikan keteduhan dan kesejukan serta mampu meredam kebisingan.

2. Fungsi sosial dan budaya

Ruang terbuka hijau bisa menjadi tempat berkumpulnya orang dalam melakukan kegiatan seperti, bermain, berolah raga dan bisa juga menjadi tempat bersilaturahmi antar warga atau masyarakat sekitar.

10. Cagar alam 
3. Fungsi estetika

Adanya ruang terbuka hijau mampu memberikan keindahan bagi suatu tempat baik itu permukiman, perkantoran atau tempattempat lainya.

\section{Fungsi Pendidikan}

Ruang terbuka hijau bisa dimanfaatkan untuk mengenal satwa-satwa dan tanaman yang ada di dalamnya. Anak-anak bisa belajar menghargai pentingnya menjaga kelestarian lingkungan dan budaya yang ada di lingkunganya dengan menjaga kelestarian alam di sekitarnya.

\section{Fungsi ekonomis}

Di area ruang teebuka hijau bisa ditata dan dikelola dengan baik sehingga bisa dimanfaatkan secara ekonomi menjadi tempat wisata, dengan begitu keberadaan ruang terbuka hijau bisa membantu menyejahterakan masyarakat sekitarnya.

Dari fungsi ruang terbuka hijau banyak manfaat yang dapat diambil diantaranya (Anonim, 2010):

1. Manfaat secara langsung yang bisa dirasakan oleh pengguna ruang terbuka hijau adalah adalah keindahan dan memberikan rasa nyaman juga kayu atau tanaman yang bisa di jual bisa langsung dimanfaatkan oleh pengelola.

2. Manfaat tidak langsung atau jangka panjang diantaranya adalah ruang terbuka hijau pembersih udara yang sangat efektif, mampu memelihara ketersediaan air tanah dan merupakan tempat pelestarian fungsi lingkungan seperti flora dan fauna.

Secara fisik RTH dapat dibedakan menjadi RTH alami berupa habitat liar alami, kawasan lindung dan taman-taman nasional serta RTH non alami atau binaan seperti taman, lapangan olahraga, pemakaman atau jalur-jaur hijau jalan.

Tipologi Ruang Terbuka Hijau (RTH) adalah sebagai berikut (Anonim, 2010):

1. Fisik : ruang terbuka hijau dibedakan menjadi ruang terbuka hijau alami berupa habitat liar alami, kawasan lindung dan taman-taman nasional serta RTH non alami atau binaan seperti taman, lapangan olahraga, pemakaman atau jalur-jaur hijau jalan.

2. Fungsi : ruang terbuka hijau berfungsi ekologis, sosial budaya, estetika, dan ekonomi.

3. Struktur ruang : ruang terbuka hijau mengikuti pola ekologis (mengelompok, memanjang, tersebar), maupun pola planologis yang mengikuti hirarki dan struktur ruang perkotaan.

4. Kepemilikan : RTH dibedakan ke dalam RTH publik dan RTH privat. 


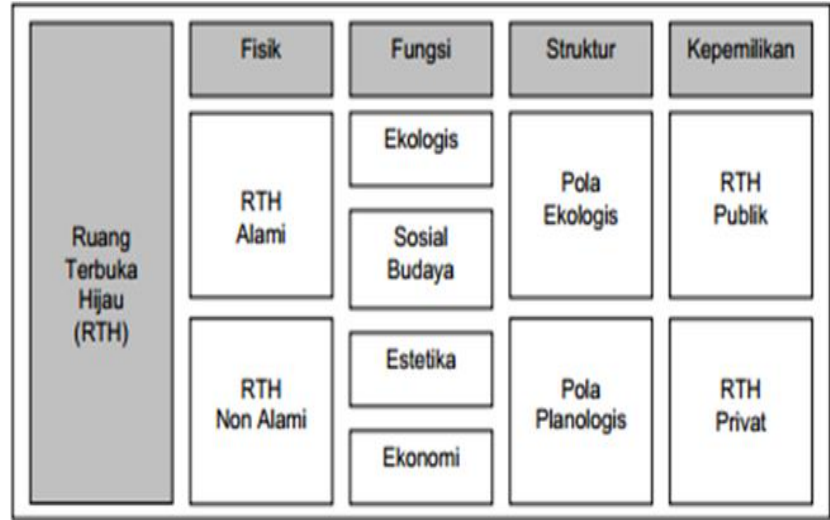

Gambar 1.

Tipologi RTH

\section{METODOLOGI}

Penelitian ini menggunakan metode kualitatif dengan pendekatan studi literatur untuk mengkaji relevansi dari jurnal ruang terbuka hijau di kampus-kampus yang ada di Indonesia. Studi literatur (kepustakaan), yaitu pengambilan data dengan cara mempelajari buku-buku dan dokumen yang berhubungan dengan pokok-pokok penelitian (Dunn, 2003).

Penelitian ini untuk mengetahui fungsi dan manfaat ruang terbuka hijau di kampus. Selain untuk arahan yang tepat yang bisa diterapkan di kampus agar dengan adanya ruang terbuka hijau kampus menjadi tempat yang nyaman untuk berkegiatan.

\section{HASIL DAN PEMBAHASAN}

Pada hasil dan pembahasan ini akan diuraikan mengenai beberapa penerapan konsep ruang terbuka hijau di beberapa kampus di Indonesia. Penerapan konsep ruang terbuka hijau diketahui dari hasil penelitian melalui jurnal-jurnal yang ada.

1. Jurnal tentang Analisisi Potensi Pemanfaatan Ruang Terbuka Hijau
DOI: doi.org/10.21009/jgg.092.04

(RTH) Kampus di Politeknik Negeri Bandung (Suciyani, 2018) .

Penelitian ini membahas mengenai potensi pemanfaatan RTH di Politeknik Bandung yang masih bisa dikembangkan sehingga menciptakan lingkungan kampus yang berkelanjutan. Dari hasil 21 titik dalam penelitian ini hanya 16 titik lokasi yang bisa dimanfaatkan menjadi ruang terbuka hijau.

Pemanfaatan ruang terbuka hijau di kampus Politeknik Bandung bisa sebagai fungsi social budaya terutama dalam mendukung segala akitifitas warga kampus sehingga bisa dipergunakan sebagai ruang publik atau ruang belajar terbuka (open learning space). Ruang terbuka hijau Politeknik Bandung juga memiliki fungsi estetika.

Dengan fungsi ini Politeknik Bandung disa dijadikan sebagai icon kampus. Selain fungsiifungsi diatas RTH juga memiliki fungsi ekonomi. Ruang terbuka hijau yang dikelola dengan baik bisa memberikan hasil yang optimal tidak hanya bagi kenyaman dan keindahan tapi nilai ekonomis yang tinggi.

\begin{tabular}{|c|l|c|l|}
\hline No & \multicolumn{1}{|c|}{ Lokasi } & $\begin{array}{c}\text { Luas } \\
\text { Lahan }\end{array}$ & $\begin{array}{l}\text { Jenis Potensi } \\
\text { (fungsi RTH) }\end{array}$ \\
\hline 1 & $\begin{array}{l}\text { Taman Menara } \\
\text { Air Utara }\end{array}$ & $961,2 \mathrm{~m} 2$ & $\begin{array}{l}\text { Estetika } \\
\text { (Icon } \\
\text { Kampus) }\end{array}$ \\
\hline 2 & $\begin{array}{l}\text { Taman di } \\
\text { samping } \\
\text { gedung } \\
\text { laboratorium } \\
\text { Aeronautika }\end{array}$ & $620,1 \mathrm{~m} 2$ & $\begin{array}{l}\text { Sosial- } \\
\text { budaya } \\
\text { (Ruang } \\
\text { Publik dan }\end{array}$ \\
\hline
\end{tabular}




\begin{tabular}{|c|c|c|c|}
\hline No & Lokasi & $\begin{array}{l}\text { Luas } \\
\text { Lahan }\end{array}$ & $\begin{array}{l}\text { Jenis Potensi } \\
\text { (fungsi RTH) }\end{array}$ \\
\hline & & & $\begin{array}{l}\text { open learning } \\
\text { space) }\end{array}$ \\
\hline 3 & $\begin{array}{l}\text { Taman di } \\
\text { depan gedung } \\
\text { administrasi } \\
\text { niaga }\end{array}$ & $184,6 \mathrm{~m} 2$ & $\begin{array}{l}\text { Sosial- } \\
\text { Budaya } \\
\text { (Ruang } \\
\text { Publik dan } \\
\text { open learning } \\
\text { space) } \\
\text { Ekonomi } \\
\text { (tanaman } \\
\text { berbuah) }\end{array}$ \\
\hline 4 & $\begin{array}{l}\text { Taman di } \\
\text { samping } \\
\text { gedung } \\
\text { Pujasera }\end{array}$ & $765 \mathrm{~m} 2$ & $\begin{array}{l}\text { Sosial- } \\
\text { Budaya } \\
\text { (Ruang } \\
\text { Publik) } \\
\text { Ekonomi } \\
\text { (budidaya } \\
\text { tanaman) }\end{array}$ \\
\hline 5 & $\begin{array}{l}\text { Taman di area } \\
\text { Parkir } \\
\text { Mahasiswa }\end{array}$ & $945 \mathrm{~m} 2$ & $\begin{array}{l}\text { Sosial- } \\
\text { Budaya } \\
\text { (ruang } \\
\text { publik) }\end{array}$ \\
\hline 6 & $\begin{array}{l}\text { Taman di } \\
\text { antara gedung } \\
\text { U dan Gedung } \\
\text { Lab Teknik } \\
\text { Mesin }\end{array}$ & $\begin{array}{c}511,98 \\
\mathrm{~m} 2\end{array}$ & $\begin{array}{l}\text { Sosial- } \\
\text { budaya } \\
\text { (Ruang } \\
\text { Publik dan } \\
\text { open } \\
\text { learning } \\
\text { space) }\end{array}$ \\
\hline 7 & $\begin{array}{l}\text { Taman di } \\
\text { depan Gedung } \\
\text { Akuntansi }\end{array}$ & $242,9 \mathrm{~m} 2$ & $\begin{array}{l}\text { Sosial- } \\
\text { budaya } \\
\text { (Ruang } \\
\text { Publik dan } \\
\text { open } \\
\text { learning } \\
\text { space) }\end{array}$ \\
\hline 8 & $\begin{array}{l}\text { Taman di di } \\
\text { antara gedung } \\
\text { lab Teknik } \\
\text { Energi dan } \\
\text { gedung kuliah } \\
\text { I }\end{array}$ & $\begin{array}{c}513,02 \\
\mathrm{~m} 2\end{array}$ & $\begin{array}{l}\text { Sosial- } \\
\text { budaya } \\
\text { (Ruang } \\
\text { Publik dan } \\
\text { open } \\
\text { learning } \\
\text { space) }\end{array}$ \\
\hline 9 & $\begin{array}{l}\text { Taman } \\
\text { disaping } \\
\text { Gedung } \\
\text { Kuliah I }\end{array}$ & $212 \mathrm{~m} 2$ & $\begin{array}{l}\text { Sosial- } \\
\text { budaya } \\
\text { (Ruang } \\
\text { Publik dan } \\
\text { open } \\
\text { learning } \\
\text { space) }\end{array}$ \\
\hline 10 & $\begin{array}{l}\text { Taman } \\
\text { diantara } \\
\text { gedung MTRI }\end{array}$ & $407 \mathrm{~m} 2$ & $\begin{array}{l}\text { Sosial- } \\
\text { budaya } \\
\text { (Ruang } \\
\text { Publik dan }\end{array}$ \\
\hline
\end{tabular}

\begin{tabular}{|c|c|c|c|}
\hline No & Lokasi & $\begin{array}{l}\text { Luas } \\
\text { Lahan }\end{array}$ & $\begin{array}{l}\text { Jenis Potensi } \\
\text { (fungsi RTH) }\end{array}$ \\
\hline & $\begin{array}{l}\text { dan gedung } \\
\text { kuliah II }\end{array}$ & & $\begin{array}{l}\text { open } \\
\text { learning } \\
\text { space) }\end{array}$ \\
\hline 11 & $\begin{array}{l}\text { Taman di area } \\
\text { Parkir } \\
\text { Mahasiswa }\end{array}$ & $\begin{array}{c}6.393,052 \\
\mathrm{~m} 2\end{array}$ & $\begin{array}{l}\text { Sosial- } \\
\text { Budaya } \\
\text { (ruang } \\
\text { publik) } \\
\text { Estetika } \\
\text { (Center Point } \\
\text { RTH) }\end{array}$ \\
\hline 12 & $\begin{array}{l}\text { Taman di } \\
\text { belakang } \\
\text { Kantin MKU }\end{array}$ & $686,4 \mathrm{~m} 2$ & $\begin{array}{l}\text { Sosial- } \\
\text { Budaya } \\
\text { (ruang } \\
\text { publik) }\end{array}$ \\
\hline 13 & $\begin{array}{l}\text { Taman di } \\
\text { sebelah barat } \\
\text { Gedung } \\
\text { T.Kom }\end{array}$ & $314 \mathrm{~m} 2$ & $\begin{array}{l}\text { Sosial- } \\
\text { Budaya } \\
\text { (ruang } \\
\text { publik) }\end{array}$ \\
\hline 14 & $\begin{array}{l}\text { Taman di } \\
\text { depan Gedung } \\
\text { Teknik } \\
\text { Komputer }\end{array}$ & $138,7 \mathrm{~m} 2$ & $\begin{array}{l}\text { Sosial- } \\
\text { budaya } \\
\text { (Ruang } \\
\text { Publik dan } \\
\text { open } \\
\text { learning } \\
\text { space) }\end{array}$ \\
\hline 15 & $\begin{array}{l}\text { Taman di } \\
\text { antara Gedung } \\
\text { teknik } \\
\text { komputer dan } \\
\text { lab teknik } \\
\text { telekomunikasi }\end{array}$ & $\begin{array}{c}250,16 \\
\mathrm{~m} 2\end{array}$ & $\begin{array}{l}\text { Sosial- } \\
\text { budaya } \\
\text { (Ruang } \\
\text { Publik dan } \\
\text { open } \\
\text { learning } \\
\text { space) }\end{array}$ \\
\hline 16 & $\begin{array}{l}\text { Taman di } \\
\text { antara Gedung } \\
\text { Welding } \\
\text { Training } \\
\text { Center dan } \\
\text { Lab. Teknik } \\
\text { Mesin }\end{array}$ & $247,6 \mathrm{~m} 2$ & $\begin{array}{l}\text { Sosial- } \\
\text { budaya } \\
\text { (Ruang } \\
\text { Publik dan } \\
\text { open } \\
\text { learning } \\
\text { space) }\end{array}$ \\
\hline
\end{tabular}

Table 1.

Potensi Penyediaan dan Pemanfaatan RTH di Kampus Polban

Ruang terbuka hijau di Polban dapat ditanami berbagai tanaman maupun buah-buahan yang bisa dijual kembali di kampus. Untuk menunjang itu semua ada baiknya ruang terbuka hijau yang ada di Politeknik Negeri Bandung dilengkapi 
dengan kursi, meja, jaringan internet yang memadai dan lampu penerangan. Kelengkapan tersebut juga meningkatkan nilai estetika bagi ruang terbuka hijau yang ada di Politeknik Negeri Bandung.

2. Kajian Tatanan Ruang Terbuka Hijau Terhadap Konsep Kampus Hijau Di Kampus Universitas Diponegoro Tembalang (Purwanto \& Setioko, 2018).

Universitas Diponegoro merupanak universitas negeri terbesar di Kota Semarang. Saat ini Universitas Diponegoro menjadi salah satu kampus yang masuk ke dalam kategori green campus di Indonesia. Universitas Diponegoro memiliki ruang terbuka hijau yang bersekala kawasan yang dimiliki okeh kampus dan dapat diakses oleh publik.

Universitas Diponegoro memiliki banyak taman yang bisa diakseh oleh warga masyarakat sekitar. Salah satu taman yang memiliki ruang terbuka hijau paling baik adalah RTH di depan Widya Puraya.
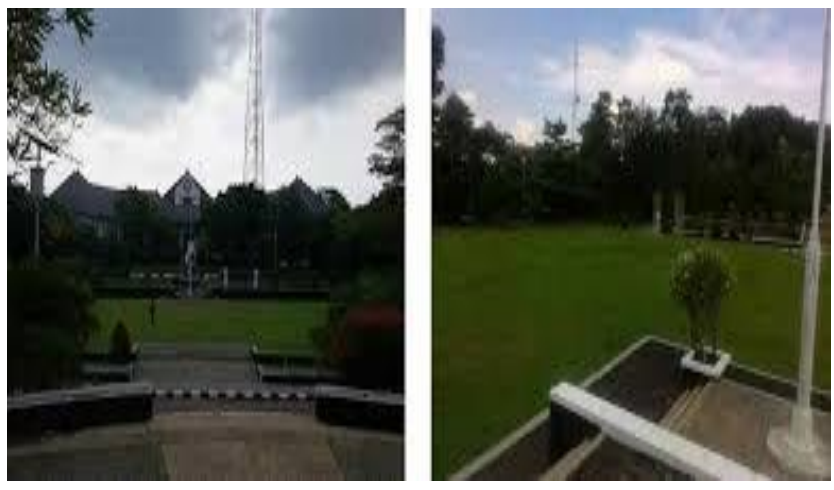

Gambar 2.

Ruang terbuka depan Gedung Widya Puraya
Dalam prinsip perencanaan dan perancangan ruang terbuka hijau Universitas Diponegoro telah syarat aspek-aspek tersebut. Aspek fungsional, aspek fisik dan non fisisk telah dirancang dengan baik oleh kampus. Dari aspek lingkungan ruang terbuka hijau di Undip sudah seibangb dengan ruang terbangun, hanya penataan dan pengelolaanya yg belum merata.

3. Analisis potensi pengembangan ruang terbuka hijau (RTH) di kampus Universitas Ahmad Dahlan Yogyakarta (Susilo \& Dhaniaputri, 2016)

Penelitian ini membahas ruang terbuka hijau dimana salah satu manfaatnya adalah fungsi ekologis. Dalam penelitian ini dibahas tentang identifikasi tanaman dan tumbuhan di Universitas Ahmad Dahlan Yogyakarta. Dalam penelitian ini juga di uraikan mengenai manfaat dan tingkat kesesuaian penanaman pohon terhadap lingkungan. Dari hasil penelitian ditemukan 17 jenis taman di sekitar wilayah kampus Universitas Ahmad Dahlan.

\begin{tabular}{|l|l|l|l|l|l|l|}
\hline \multirow{2}{*}{ No } & \multirow{2}{*}{$\begin{array}{l}\text { Nama } \\
\text { Spesies }\end{array}$} & \multicolumn{5}{|c|}{ Bagian Daun yang Diamati } \\
\cline { 3 - 7 } & $\begin{array}{l}\text { Termin } \\
\text { alia } \\
\text { catappa } \\
\text { L. }\end{array}$ & $\begin{array}{l}\text { Merun } \\
\text { cing }\end{array}$ & Tumpul & Rata & Berbulu & Hijau \\
\hline 2 & $\begin{array}{l}\text { Ficus } \\
\text { lyrata } \\
\text { Warb. }\end{array}$ & Tumpul & Berlekuk & $\begin{array}{l}\text { Bero } \\
\text { mba } \\
k\end{array}$ & Licin & Hijau \\
\hline 3 & $\begin{array}{l}\text { Euphor } \\
\text { ia } \\
\text { longan } \\
\text { a } \\
\text { Lamk. }\end{array}$ & Runcing & Runcing & Rata & Licin & Hijau \\
\hline
\end{tabular}


JGG-Jurnal Green Growth dan Manajemen Lingkungan p-ISSN: 2303-2332; e-ISSN: 2597-8020

Vol. 9 No. 2 Desember 2020

DOI: doi.org/10.21009/jgg.092.04

\begin{tabular}{|c|c|c|c|c|c|c|}
\hline \multirow[b]{2}{*}{ No } & \multirow{2}{*}{$\begin{array}{l}\text { Nama } \\
\text { Spesies }\end{array}$} & \multicolumn{5}{|c|}{ Bagian Daun yang Diamati } \\
\hline & & Ujung & Pangkal & Tepi & $\begin{array}{l}\text { Permu } \\
\text { kaan }\end{array}$ & Warna \\
\hline 4 & $\begin{array}{l}\text { Mangif } \\
\text { era } \\
\text { indica } \\
\text { L. }\end{array}$ & Tumpul & Tumpul & Rata & Licin & Hijau \\
\hline 5 & $\begin{array}{l}\text { Persea } \\
\text { americ } \\
\text { ana L. }\end{array}$ & Runcing & Runcing & Rata & Licin & Hijau \\
\hline 6 & $\begin{array}{l}\text { Spondi } \\
\text { as } \\
\text { pinnata } \\
\text { (L.f) } \\
\text { Kurz. }\end{array}$ & $\begin{array}{l}\text { Merunci } \\
\text { ng }\end{array}$ & Meruncing & Rata & Licin & Hijau \\
\hline 7 & $\begin{array}{l}\text { Roysto } \\
\text { nea } \\
\text { regia } \\
\text { (H. B. } \\
\text { K) O. } \\
\text { F. } \\
\text { Cook. }\end{array}$ & Runcing & Tumpul & Rata & Licin & Hijau \\
\hline 8 & $\begin{array}{l}\text { Crysop } \\
\text { hyllum } \\
\text { cainito } \\
\text { L. }\end{array}$ & Tumpul & Tumpul & Rata & Licin & $\begin{array}{c}\text { Hijau } \\
\text { tua } \\
\text { permuk } \\
\text { an atas, } \\
\text { coklat } \\
\text { permuk } \\
\text { aan } \\
\text { bawah }\end{array}$ \\
\hline 9 & $\begin{array}{l}\text { Manilk } \\
\text { ara } \\
\text { kauki } \\
\text { (L) } \\
\text { Dubard } \\
\text {. }\end{array}$ & Tumpul & Meruncing & Rata & Licin & $\begin{array}{l}\text { Hijau } \\
\text { tua } \\
\text { permuk } \\
\text { an atas, } \\
\text { coklat } \\
\text { permuk } \\
\text { aan } \\
\text { bawah }\end{array}$ \\
\hline 10 & $\begin{array}{l}\text { Polyalth } \\
\text { ia } \\
\text { longifoli } \\
\text { a } \\
\text { (Sonner } \\
\text { at) } \\
\text { Thwait. }\end{array}$ & Runcing & Tumpul & $\begin{array}{l}\text { Bero } \\
\text { mba k }\end{array}$ & $\begin{array}{l}\text { Licin } \\
\text { mengkil } \\
\text { a t }\end{array}$ & Hijau \\
\hline 11 & $\begin{array}{l}\text { Thuja } \\
\text { orientali } \\
\text { s L. }\end{array}$ & Runcing & Runcing & Rata & $\begin{array}{l}\text { Berbulu } \\
\text { kasar }\end{array}$ & $\begin{array}{l}\text { Hijau } \\
\text { tua }\end{array}$ \\
\hline 12 & $\begin{array}{l}\text { Micheli } \\
\text { a alba } \\
\text { DC. }\end{array}$ & Runcing & Runcing & Rata & Licin & Hijau \\
\hline 13 & $\begin{array}{l}\text { Perone } \\
\text { ma } \\
\text { canesce } \\
\text { ns } \\
\text { Jack. }\end{array}$ & Runcing & Runcing & $\begin{array}{l}\text { Bero } \\
\text { mba } \\
\mathrm{k}\end{array}$ & Licin & Hijau \\
\hline 14 & $\begin{array}{l}\text { Swieteni } \\
\text { a } \\
\text { mahago } \\
\text { ni } \\
\text { Jacq. }\end{array}$ & Runcing & Runcing & Rata & Licin & Hijau \\
\hline 15 & & & & & & \\
\hline
\end{tabular}

\begin{tabular}{|c|c|c|c|c|c|c|}
\hline \multirow[b]{2}{*}{ No } & \multirow{2}{*}{$\begin{array}{l}\text { Nama } \\
\text { Spesies }\end{array}$} & \multicolumn{5}{|c|}{ Bagian Daun yang Diamati } \\
\hline & & Ujung & Pangkal & Tepi & $\begin{array}{l}\text { Permu } \\
\text { kaan }\end{array}$ & Warna \\
\hline & $\begin{array}{l}\text { Munting } \\
\text { ia } \\
\text { calabura } \\
\text { L. }\end{array}$ & Runcing & berlekuk & $\begin{array}{l}\text { Berge } \\
\text { rigi }\end{array}$ & $\begin{array}{l}\text { Berbulu } \\
\text { halus }\end{array}$ & Hijau \\
\hline 16 & $\begin{array}{l}\begin{array}{l}\text { Arundin } \\
\text { aria } \\
\text { japonica }\end{array} \\
\text { Sieb \& } \\
\text { Zusc ex } \\
\text { Steud. }\end{array}$ & Runcing & Tumpul & Rata & Kasap & Hijau \\
\hline 17 & $\begin{array}{l}\text { Artocar } \\
\text { pus } \\
\text { integra } \\
\text { Merr. }\end{array}$ & $\begin{array}{l}\text { Merunci } \\
\text { ng }\end{array}$ & Tumpul & Rata & & \\
\hline
\end{tabular}

Table 2.

Hasil Pengamatan Ciri Morfologi Daun Pada Pohon yang ada di kampus 1, 2, 3 dan 5 UAD

\begin{tabular}{|c|c|c|c|}
\hline No. & Nama Spesies & Manfaat & $\begin{array}{c}\text { Bagian } \\
\text { Tanaman }\end{array}$ \\
\hline \multirow[t]{2}{*}{1.} & \multirow{2}{*}{$\begin{array}{l}\text { Terminalia } \\
\text { catappa } \mathrm{L} .\end{array}$} & Pohon peneduh & \\
\hline & & Antidiabetes & Buah \\
\hline \multirow[t]{2}{*}{2.} & \multirow[t]{2}{*}{$\begin{array}{l}\text { Ficus lyrata } \\
\text { Warb. }\end{array}$} & $\begin{array}{c}\text { Pohon peneduh dan tepi } \\
\text { jalan }\end{array}$ & \\
\hline & & Pakan unggas & Buah \\
\hline \multirow[t]{2}{*}{3.} & \multirow{2}{*}{\begin{tabular}{|l|} 
Euphoria \\
longana Lamk.
\end{tabular}} & Pohon peneduh & \\
\hline & & $\begin{array}{c}\text { Penyembuhan luka } \\
\text { pasca pencabutan gigi }\end{array}$ & Kulit dan biji \\
\hline \multirow[t]{2}{*}{4.} & \multirow{2}{*}{$\begin{array}{l}\text { Mangifera } \\
\text { indica } \mathrm{L} \text {. }\end{array}$} & Pohon tepi jalan & \\
\hline & & $\begin{array}{c}\text { Saluran pencernaan, } \\
\text { antioksidan }\end{array}$ & Buah \\
\hline \multirow[t]{2}{*}{5.} & \multirow{2}{*}{$\begin{array}{l}\text { Persea } \\
\text { americana } \mathrm{L} .\end{array}$} & Pohon tepi jalan & \\
\hline & & Antioksidan & Biji \\
\hline 6. & $\begin{array}{l}\text { Spondias } \\
\text { pinnata (L.f) } \\
\text { Kurz. }\end{array}$ & Antituberkulosis & Daun \\
\hline 7. & $\begin{array}{l}\text { Roystonea } \\
\text { regia }(\text { H. B. K) } \\
\text { O. F. } \\
\text { Cook. }\end{array}$ & Tanaman hias & - \\
\hline \multirow[b]{2}{*}{8.} & \multirow[b]{2}{*}{$\begin{array}{l}\text { Crysophyllum } \\
\text { cainito L. }\end{array}$} & Pohon tepi jalan & \\
\hline & & $\begin{array}{l}\text { Menurunkan tekanan } \\
\text { darah tinggi, diabetes, } \\
\text { magh, menjaga } \\
\text { kesehatan tulang, dan } \\
\text { gigi }\end{array}$ & Buah \\
\hline \multirow{3}{*}{9.} & \multirow{3}{*}{$\begin{array}{l}\text { Manilkara } \\
\text { kauki (L) } \\
\text { Dubard. }\end{array}$} & Pohon tepi jalan & \\
\hline & & Diare dan diabetes & Buah \\
\hline & & $\begin{array}{l}\text { Patung, ukiran, dan } \\
\text { tiang penyangga }\end{array}$ & Batang \\
\hline
\end{tabular}




\begin{tabular}{|c|c|c|c|}
\hline No. & Nama Spesies & Manfaat & $\begin{array}{c}\text { Bagian } \\
\text { Tanaman }\end{array}$ \\
\hline \multirow[t]{2}{*}{10.} & \multirow{2}{*}{$\begin{array}{l}\text { Polyalthia } \\
\text { longifolia } \\
\text { (Sonnerat) } \\
\text { Thwait. }\end{array}$} & $\begin{array}{l}\text { Pohon tepi jalan, } \\
\text { tanaman pagar dan } \\
\text { penghias taman }\end{array}$ & \\
\hline & & $\begin{array}{c}\text { Akumulator zat } \\
\text { pencemar di udara }\end{array}$ & Daun \\
\hline \multirow[t]{2}{*}{11.} & \multirow{2}{*}{$\begin{array}{l}\text { Thuja } \\
\text { orientalis L. }\end{array}$} & Tanaman hias & \\
\hline & & $\begin{array}{c}\text { obat batuk, demam, dan } \\
\text { diare }\end{array}$ & Daun \\
\hline \multirow{3}{*}{12.} & \multirow{3}{*}{$\begin{array}{l}\text { Michelia alba } \\
\text { DC. }\end{array}$} & Pohon tepi jalan & \\
\hline & & Antioksidan & Bunga \\
\hline & & $\begin{array}{c}\text { Dieuretik memecah } \\
\text { batu ginjal }\end{array}$ & Bunga, batang, \\
\hline \multirow[t]{2}{*}{13.} & \multirow{2}{*}{\begin{tabular}{|l|} 
Peronema \\
canescens Jack.
\end{tabular}} & Pohon tepi jalan & \\
\hline & & $\begin{array}{l}\text { Antiplasmodium dan } \\
\text { obat demam }\end{array}$ & Daun \\
\hline \multirow[t]{2}{*}{14.} & \multirow{2}{*}{\begin{tabular}{|l|} 
Swietenia \\
mahagoni Jacq.
\end{tabular}} & Pohon peneduh & \\
\hline & & $\begin{array}{c}\text { Menurunkan kadar gula } \\
\text { darah }\end{array}$ & Biji \\
\hline 15. & $\begin{array}{l}\text { Muntingia } \\
\text { calabura L. }\end{array}$ & $\begin{array}{c}\text { Antioksidan, } \\
\text { antiinflamasi, } \\
\text { antibakteri }\end{array}$ & Daun \\
\hline 16. & $\begin{array}{l}\text { Arundinaria } \\
\text { japonica } \text { Sieb } \\
\& \text { Zusc ex } \\
\text { Steud. }\end{array}$ & $\begin{array}{l}\text { Tanaman hias dapat } \\
\text { dijadikan pagar } \\
\text { tanaman }\end{array}$ & - \\
\hline \multirow[t]{3}{*}{17.} & \multirow{3}{*}{$\begin{array}{l}\text { Artocarpus } \\
\text { integra Merr. }\end{array}$} & $\begin{array}{c}\text { Pohon tepi jalan dan } \\
\text { peneduh }\end{array}$ & \\
\hline & & Obat batuk, tonik & Biji \\
\hline & & $\begin{array}{c}\text { Anti kanker, antivirus, } \\
\text { antiinflamasi, diuretik } \\
\text { dan } \\
\text { antihipertensi }\end{array}$ & $\begin{array}{l}\text { Kulit batang } \\
\text { kayu }\end{array}$ \\
\hline
\end{tabular}

Table 3.

Manfaat pohon dan bagian-gagian tanaman yang dapat dimanfaatkan

Dari hasil penelitian yang dilakukan di Universitas Ahmad Dahlan Yogyakarta ini didapat bahwa di Universitas Ahmad Dahlan memiliki banyak jenis vegetasi. Ada sekitar 17 tanaman atau vegetasi yang tumbuh di Universitas Ahmad Dahlan. Dari berbagai jenis tanamn yang tumbuh tersebut kesemuanya memiliki banyak manfaat masing-masing.

Masing-masing tanaman yang tumbuh di Universitas Ahmad Dahlan Yogyakarta memiliki kesesuaian letak penanaman dan peruntukannya bagi lingkungan. Hanya beberapa tanaman saka yang masih belum sesuai peruntukannya.

4. Analisis Kecukupan Ruang Terbuka Hijau Sebagai Penyerap Emisi Gas Karbon Dioksida ( CO 2 ) pada Kawasan Kampus ITS Sukolilo, Surabaya (Regina et al., 2016)

Penelitian yang dilakukan di kawasan kampus ITS Sukolilo Surabaya ini membahas tentang fungsi ruang terbuka hijau sebagai penyerap emisi gas karbon dioksida $\left(\mathrm{CO}_{2}\right)$. Kampus Institut Teknologi Sepuluh November memiliki program eco campus dalam menciptakan kampus berkelanjutan. Program ini sebagai wujud keperdulian ITS terhadap isu yang sedang berkembang saat ini yaitu isu pemanasan global.

Pemanasan global yang terjadi selama ini salah satu factor penyebabnya adalah gas efek rumah kaca yang dihasilkan dari gas $\mathrm{CO}_{2}$. Gas $\mathrm{CO}_{2}$ atau karbon dioksida terbesar di hasilkan dari asap kendaran bermotor atau alat transportasi yang tidak ramah lingkungan. Sebagai kampus yang memiliki program eco campus maka kecukupan ruang terbuka hijau menjadi syarat utama untuk terpenuhinya program tersebut. 
Karbon dioksida yang dihasilkan oleh kendaraan bermotor di ITS menjadi permasalahan tersendiri bagi kampus. Perencanaan ulang program RTH di its diharapkan dapat memperbaiki keadaan ruang terbuka hijau yang ada dan juga dapat menjadi daya serap bagi rth yang tersedia.

Pada penelitian ini akan ditentuka zona mana saja yang memiliki beban emisi yang berat karena dilalui banyak kendaraan. Dari klasifikai zona tersebut akan diketahui kepadatan kendaraan yang melewatinya dan akan disesuaikan luasan kenutuhan ruang terbuka hijaunya. Zona-zona tersebut terbagi ke dalam 8 zona yaitu:

1. Pos SKK Bundaran ITS sampai Bundaran Manarul.

2. Bundaran Manarul sampai Bundaran SCC.

3. Bundaran SCC sampai Jurusan Biologi.

4. Gor Bulutangkis sampai Pos SKK Jl. Arief Rachman Hakim.

5. Jurusan Biologi sampai Jl. Teknik Mesin berakhir.

6. Depan perumdos Blok U (Jl. Teknik Kimia).

7. Gedung Riset sampai Jurusan Teknik Informatika.

8. Jurusan Teknik Informatika sampai Pos SKK ITS Politeknik.

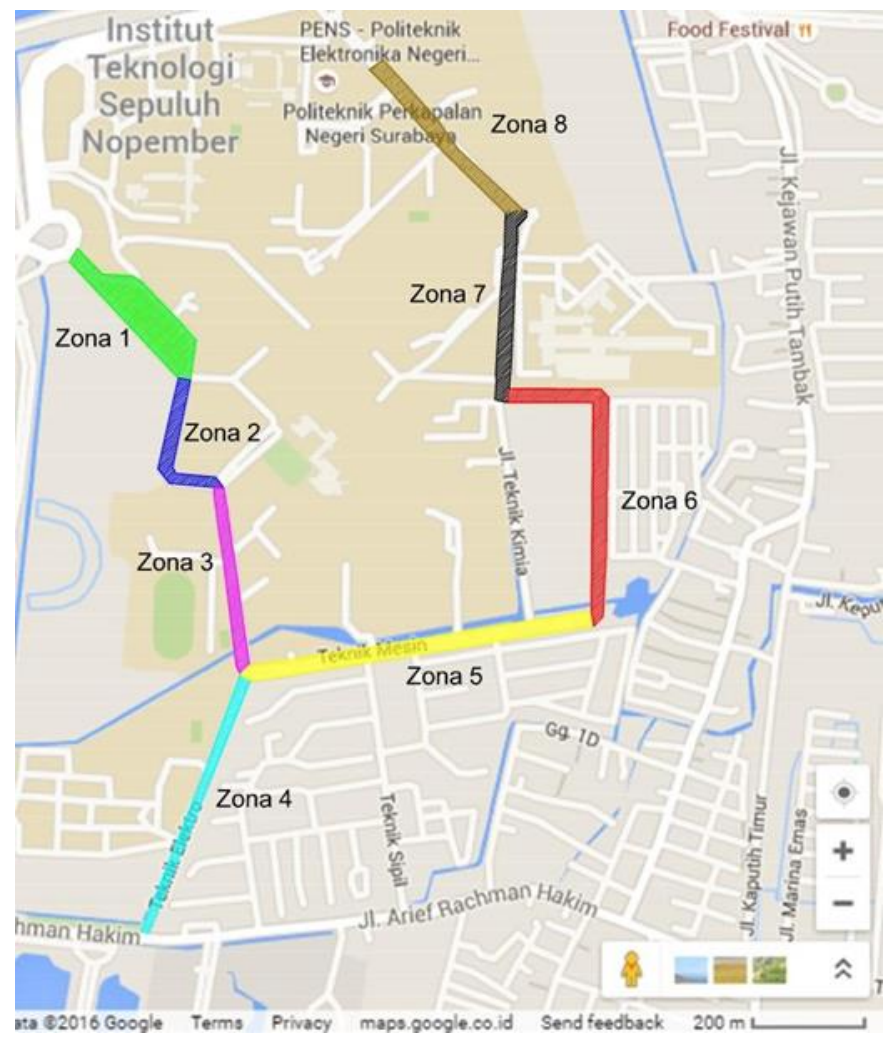

Gambar 3.

Pembagian zona analisis emisi

Setelah ditentukan zona selanjutnya dikumpulkan data-data yang dibutuhkan. Data yang dibutuhkan seperti traffic counting dan jumlah dan jenis vegetasi eksisting. Data tersebut akan dianalisis untuk dipengelolaan traffic counting, proyeksi kendaraan di tahuntahun mendatang, pehitungan emisi karbon dari kendaraan, perhitungan daya serap ruang terbuka hijau yang ada, evaluasi dan perencanaan ruang terbuka hijau jalan dan SOP ruang terbuka hijau jalan. 


\begin{tabular}{|c|c|c|c|c|c|}
\hline \multirow[t]{2}{*}{ Zona } & \multirow{2}{*}{$\begin{array}{c}\text { Jenis } \\
\text { kendaraan }\end{array}$} & \multicolumn{2}{|c|}{$\begin{array}{l}\text { Rata-rata per hari } \\
\text { (kendaraan/6jam) }\end{array}$} & \multicolumn{2}{|c|}{$\begin{array}{r}\text { Rata-rata per jam } \\
\text { (kendaraan/jam) }\end{array}$} \\
\hline & & Tiap Jenis & Total & Tiap Jenis & Tota \\
\hline & Mobil & 1.778 & \multirow{2}{*}{8.641} & 296 & \multirow{2}{*}{1.440} \\
\hline & Motor & 6.863 & & 1.144 & \\
\hline \multirow{2}{*}{2} & Mobil & 1.719 & \multirow{2}{*}{8.207} & 286 & \multirow{2}{*}{1.368} \\
\hline & Motor & 6.488 & & 1.081 & \\
\hline \multirow{2}{*}{3} & Mobil & 2.303 & \multirow[b]{2}{*}{11.380} & 384 & \multirow{2}{*}{1.897} \\
\hline & Motor & 9.077 & & 1.513 & \\
\hline \multirow[t]{2}{*}{4} & Mobil & 1.887 & \multirow{2}{*}{6.953} & 314 & \multirow{2}{*}{1.159} \\
\hline & Motor & 5.066 & & 844 & \\
\hline \multirow{2}{*}{5} & Mobil & 2.920 & \multirow{2}{*}{12.659} & 487 & \multirow{2}{*}{2.110} \\
\hline & Motor & 9.739 & & 1.623 & \\
\hline \multirow[b]{2}{*}{6} & Mobil & 1.790 & \multirow{2}{*}{13.255} & 298 & \multirow{2}{*}{2.209} \\
\hline & Motor & 11.465 & & 1.911 & \\
\hline \multirow{2}{*}{7} & Mobil & 1.061 & \multirow{2}{*}{6.537} & 177 & \multirow{2}{*}{1.089} \\
\hline & Motor & 5.476 & & 913 & \\
\hline \multirow{2}{*}{8} & Mobil & 909 & \multirow{2}{*}{4.865} & 152 & \multirow{2}{*}{811} \\
\hline & Motor & 3.956 & & 659 & \\
\hline
\end{tabular}

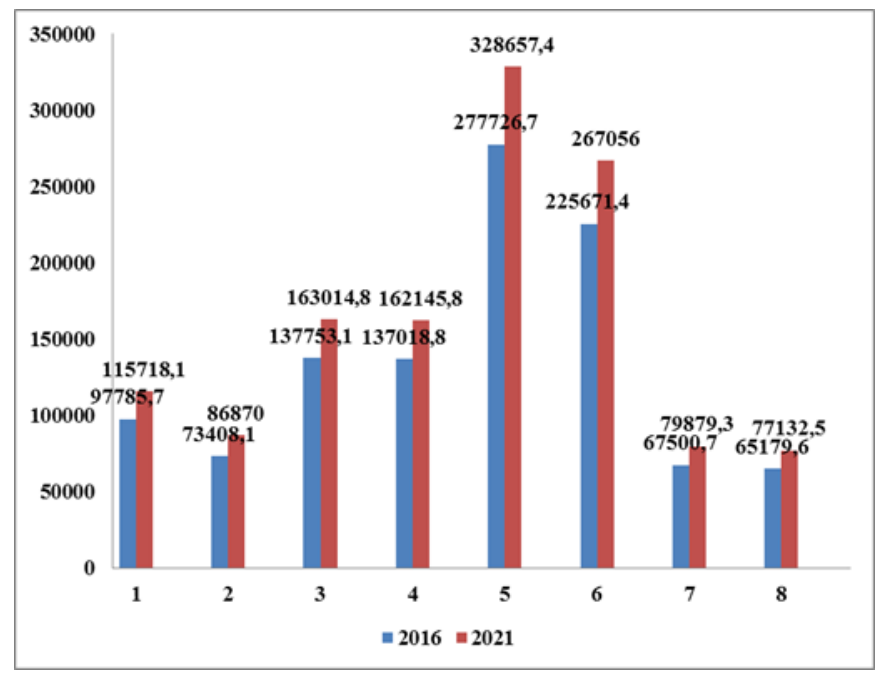

Gambar 6.

Beban Emisi (g/jam) pada Tahun 2016 dan 2021

\section{Gambar 4.}

Rata-rata kendaraan yang melintas

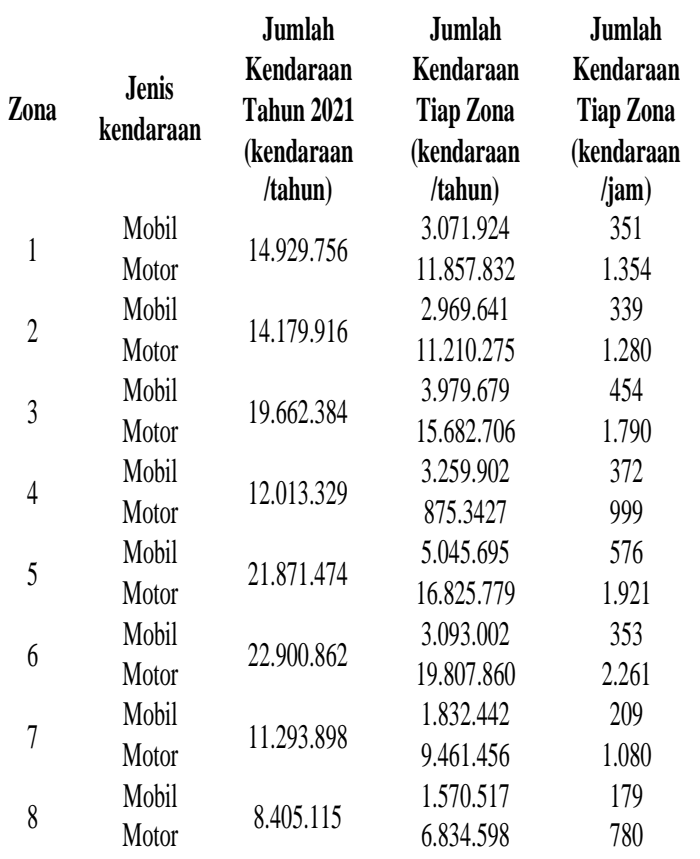

\section{Gambar 5.}

Proyeksi kendaraan tahun 2021

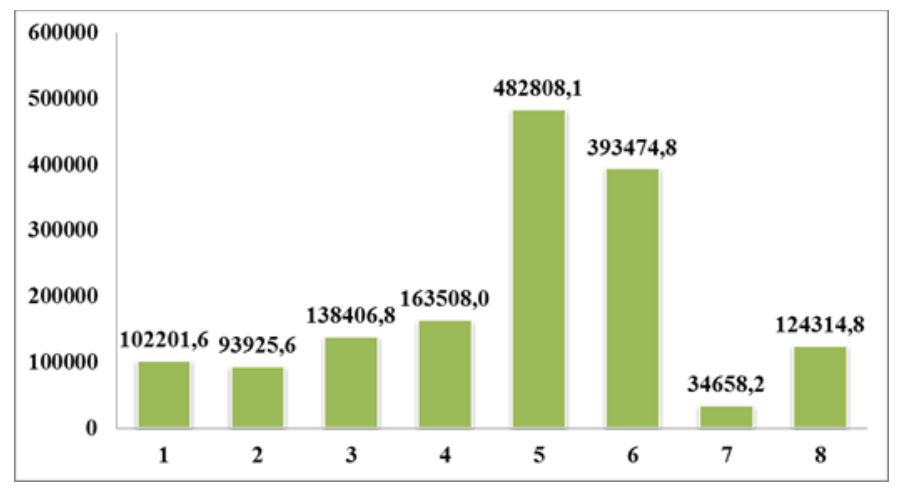

Gambar 7.

Daya Serap RTH Eksisting

Dari data-data tersebut diketahui tiaptiap zona memiliki yang berbeda-beda. Terdapat 5 zona yang memiliki daya serap yang memenuhi standar dengan ruang terbuka hijau yaitu zona 2, 4, 5, 6 dan 8. Sedangkan zona lainya yaitu zina 1, 3 dan 7 direncanakan aka ditambah dengan penanamn 46 pohon angsana.

\section{KESIMPULAN}

Dari beberapa penelitian tentang ruang terbuka hijau menguraikan tentang fungsi dan manfaat dari rung terbuka hijau yang ada di 
kampus. Pemanfaatan ruang terbuka hijau yang belum sesuai sering menjadi permasalahan tersendiri dari pihak pengelola kampus. Ketidakseimbangan antar ruang terbangun dengan ruang terbuka hijau bisa memicu banyak masalah.

Saat ini pemerintah sudah mulai banyak membangun ruang terbuka hijau di berbagai lokasi, ruang terbuka hijau tersebut dijadikan taman rekreasi bagi warga sekitarnya. Beberapa kampus-kampus besar di Indonesia pun kini sudah banyak menerapkan konsep ruang terbuka hijau agar terciptanya kondisi yang nyaman dalam setiap kegiatan belajar mengajar. kampus-Kampus yang sudah menerapkan konsep tersebut diantanya:

1. Politeknik Negeri Bandung, di kampus ini dari 21 titik yang diteliti 16 diantaranya bisa dioptimalkan penggunaannya sehingga bisa menjadi open learning space dan berpotensi memiliki fungsi estetika sehingga bisa jadi icon kampus.

2. Universitas Diponegoro, Undip merupakan salah satu kampus hijau versi greenmetric UI tahun 2014 dengan menempati peringkat 5 dari sepuluh besar kampus hijau di Indonesia. Tidak heran jika Undip memiliki ruang terbuka hijau sebesar 73,60\% dari total 198 ha luasnya. Dilihat dari aspek lingkungan Universitas Diponegoro memiliki
DOI: doi.org/10.21009/jgg.092.04

ruang terbangun dan terbuka yang seimbang.

3. Universitas Ahmad Dahlan Yogjakarta, UAD memiliki ruang terbuka hijau yang ditanami berbagai jenis vegetasi yang bisa dimanfaatkan secara langsung oleh pengelola kampus. Jenis vegetasi yang ada bukan hanya tempat berteduh akan tetapi jenis-jenis tanaman obat-obatan. Pola tanam di RTH Universitas Ahmad Dahlam sudah sesuai letak dan peruntukannya.

4. Institute Teknologi Sepuluh November Surabaya, merupakan kampus yang memiliki program eco campus. Ruang terbuka hijau yang ada di ITS sangan bermanfaat terutama sebagai penyerap emosi gas kaca karbon dioksida $\left(\mathrm{CO}_{2}\right)$ yang dihasilkan dari kendaraankendaraan yang melewati kampus. Peningkatan fungsi ruang terbuka hijau di kampus ITS dilakukan agar gas $\mathrm{CO}_{2}$ yang di hasilkan oleh kendaraan bermotor dapat diatur dengan adanya ruang terbuka hijau tersebut.

\section{DAFTAR PUSTAKA}

Anonim. (2010). Ruang Terbuka Hijau. Retrieved February 15, 2020, from http://www.penataanruang.com/ruangterbuka-hijau.html

Beddu, S. (2015). Penataan Ruang Terbuka Hijau Kawasan Kampus II Universitas Islam Negeri (UIN) Alauddin Makassar di Kabupaten Gowa. Jurnal Plano 
Madani, 4(1), 1-11.

Bertiyanti, N. I. (2018). Analisis Kebutuhan Ruang Terbuka Hijau ( RTH ) kawasan padat di Kota Bandung. Retrieved from https://www.researchgate.net/publicatio $\mathrm{n} / 325312226$

Dunn, W. N. (2003). Analisis Kebijakan Publik. Yogyakarta: Gadjah Mada. University Press.

Hamdaningsih, S. S., Fandeli, C., \& Baiquni, M. (2013). Studi Kebutuhan Hutan Kota Berdasarkan Kemampuan Vegetasi Dalam Penyerapan Karbon di Kota Mataram. Majalah Geografi Indonesia, 24(1), 1-9.

Hermawan, D., Pramitasari, D., \& Sudibyo, S. (2017). Studi Kecukupan Ruang Terbuka Hijau Ideal Di Kampus Perguruan Tinggi Untuk Perencanaan Kampus Hijau Kasus Amatan Wilayah Aglomerasi Kota Yogyakarta Utara. In Prosiding Seminar Nasional XII "Rekayasa Teknologi dan Informasi 2017" Sekolah tinggi Teknologi Nasional Yogyakarta (pp. 399-404).

Kementrian Dalam Negri. (2007). Peraturan Menteri Dalam Negeri Nomor 1 Tahun 2007 Tentang Penataan Ruang Hijau Kawasan Perkotaan. https://doi.org/10.2320/materia.46.171

Kementrian Pekerjaan Umum. (2008). Peraturan Menteri Pekerjaan Umum. Direktorat Jendral Penataan Ruang Departemen Pekerjaan Umum.

Koto, A. G., \& Taslim, I. (2019). Kajian Ruang Terbuka Hijau Kampus Universitas Muhammadiyah Gorontalo Menggunakan Foto Udara Drone. Media Komunikasi Geografi, 19(2), 153. https://doi.org/10.23887/mkg.v19i2.147 35

Lapian, H. (2015). Ruang Terbuka Hijau di Perkotaan. Retrieved from https://www.kompasiana.com/haprylapi an/550dce6f813311d22bb1e606/ruang- terbuka-hijau-di-kampus-meningkatkankualitas-mahasiswa

Mochamad, aaron Z., Rogomulyo, R., \& Rofiko, N. S. (2015). Kajian Fungsi Ruang Terbuka Hijau Fakultas Pertanian Universitas Gadjah Mada. Jurnal Vegetika, 4(1), 15-28.

Nugradi, D. N. A. (2009). Identifikasi ruang terbuka hijau Kota Semarang. Jurnal Teknik Sipil Dan Perencanaan, 11(1), 61-70. Retrieved from https://journal.unnes.ac.id/nju/index.php /jtsp/article/view/6967

Purwanto, E., \& Setioko, B. (2018). Kajian Tatanan Ruang Terbuka Hijau Terhadap Konsep Kampus Hijau Di Kampus Universitas Diponegoro Tembalang. Modul, $18(1), \quad 9$. https://doi.org/10.14710/mdl.18.1.2018. 9-16

Regina, R., Mangkoedihardjo, S., Lingkungan, J. T., Teknik, F., Teknologi, I., Nopember, S., ... Indonesia, S. (2016). Analisis Kecukupan Ruang Terbuka Hijau Sebagai Penyerap Emisi Gas Karbon Dioksida ( CO 2 ) pada Kawasan Kampus ITS Sukolilo , Surabaya. Jurnal Teknik ITS, 5(2).

Samsudi. (2010). Ruang Terbuka Hijau Kebutuhan Tata Ruang Perkotaan Kota Surakarta. Jurnal Rural and Development, 1(1), 11-19.

Shani, F. M., \& Kurniawan, A. (2015). Kajian Ketersediaan dan Kebutuhan Ruang Terbuka Hijau Kawasan Perkotaan Di Kota Sukabumi. Jurnal Bumi Indonesia, 4, 1-8. Retrieved from http://lib.geo.ugm.ac.id/ojs/index.php/jb i/article/view/366

Siregar, M. Y. A. H. (2014). Fungsi Ruang Terbuka Hijau Dalam Tata Ruang Kota Ditinjau Dari Perspektif Hukum Administrasi Negara (Studi Kasus Pemerintah Kota Medan). 
Suciyani, W. O. (2018). Analisis Potensi Pemanfaatan Ruang Terbuka Hijau (Rth) Kampus Di Politeknik Negeri Bandung. Jurnal Planologi, 15(1), 17. https://doi.org/10.30659/jpsa.v15i1.274 2

Supriyatno, B. (2009). Manajemen Tata Ruang (Cetakan Pe). Tanggerang: CV. Media Berlian.

Susilo, M. J., \& Dhaniaputri, R. (2016). Analisis Potensi Pengembangan Ruang Terbuka Hijau (RTH) Di Kampus Universitas Ahmad Dahlan Yogyakarta. In Prosiding Seminar Nasional II Tahun 2016 (pp. 782-811). 